\section{Campagne FARE Wireline Reentry of DSDP Hole 396B Using the NADIA System}

PAGES 729-730, 741

\section{Jacques Legrand,' André Echardour,' Henri Floc'h,' Luc Floury, ${ }^{1}$ Joris Gieskes, ${ }^{2}$ François Harmegnies, ${ }^{1}$ Gerard Loaec, ${ }^{1}$ Jean-Pierre Pozzi, ${ }^{3}$ Yves Raer, ${ }^{1}$ and Ralph Stephen ${ }^{1}$}

In July 1988, IFREMER (Institut Français de Recherche pour l'Exploitation de la Mer) carried out the first wireline reentry of a borehole on the deep seafloor using the NADIA (Navette de Diagraphie) system at DSDP Site $396 \mathrm{~B}$ near the MidAtlantic Ridge and the Kane Fracture Zone. Water depth was $4455 \mathrm{~m}$. The project was called Campagne FARE (faisabilité Re-Entrée). The NADIA system is a cone-shaped aluminum frame emplaced on the reentry cone by the deep-sea submersible Nautile. Nautile also provides the hydraulic power and electric control signals to run the winch on NADIA that lowers logging tools into the borehole. Five logging runs were made: a water sampler (outside diameter of $100 \mathrm{~mm}$ ) was lowered to $170 \mathrm{~m}$ into the hole, which was cased to $170 \mathrm{~m}$; a temperature probe (outside diameter of $200 \mathrm{~mm}$ ) was lowered to $204 \mathrm{~m}$; the water sampler was run again to a depth of $301 \mathrm{~m}$ (130 m into open hole in basalt); a dummy probe (outside diameter of $150 \mathrm{~mm}$ ) was lowered to $301 \mathrm{~m}$; and the temperature probe was run a second time to $301 \mathrm{~m}$. The total hole depth was originally $405 \mathrm{~m}$, and it appears that the hole has filled in about $100 \mathrm{~m}$ (all depths are quoted to $\pm 5 \mathrm{~m}$ ). The measurements indicate that bottom water is still flowing into the hole 12 years after drilling. Wireline reentry is an exciting new technological development that will enable use of deep-sea boreholes for geoscience experiments after the drill ship leaves.

\section{Introduction}

This paper describes the successful field test of the NADIA (Navette de Diagraphie, which means logging shuttle) wireline reentry

\footnotetext{
${ }^{1}$ IFREMER, Plouzane Cedex, France.

${ }^{2}$ Scripps Institution of Oceanography, La Jolla, Calif.

${ }^{3}$ Département de Géologie, Ecole Normale Supérieure/CNRS, Paris, France.

${ }^{4}$ Woods Hole Oceanographic Institution, Woods Hole, Mass.
}

Cover. NADIA is a deep-sea device for reentering DSDP boreholes with logging tools. It is a project of IFREMER (Institut Français de Recherche Pour l'Exploitation de la Mer) and is deployed with their deep-sea submersible, Nautile. The photo shows NADIA in the reentry cone of DSDP Hole 396B during engineering tests in July-August 1988. This was the first time that reentry of deep-sea boreholes has been carried out without the drill ship.

See "Campagne FARE: Wireline Reentry of DSDP Hole 396B Using the NADIA System," by Jacque Legrand et al., page 729. tests in July 1988 in DSDP (Deep Sea Drilling Project) Hole 396B (near the Kane Fracture Zone at the Mid-Atlantic Ridge (Figure 1)) demonstrated the feasibility of routine reentry and logging in a water depth of $4455 \mathrm{~m}$.

The NADIA system [Legrand et al., 1988] is emplaced on the reentry cone by the deepsea submersible Nautile. Nautile also provides the hydraulic power and electrical control sig nals to run the winch on NADIA that lowers and raises logging tools in the borehole. $A$ custom-made deep-sea hydraulic and electrical connector enables Nautile to connect and disconnect from NADIA at depth.

One previous attempt at wireline reentry was made from the D/V Glomar Challenger on DSDP Leg 88 [Stephen et al., 1987]. A reentry sled with scanning sonar and a transponder was lowered $3000 \mathrm{~m}$ below the drill ship and its response to ship motion was monitored. However, the sled did not carry a logging tool and the hole on the seafloor was not located.

Boreholes on the deep ocean floor are not merely relics of a sample acquisition proce-

TABLE 1. Experiments That Can Utilize Wireline Reentry Capability

Magnetotellurics

Nested Packer Array

Resettable Straddle Packer

Long-Term Monitoring and Sampling of Pore Fluids

Borehole Gravity

Side Wall Sampling

Physical Properties Measurements

Magnetic Logging

Offset Vertical Seismic Profiles

Zero Offset Vertical Seismic Profiles

Cross-Hole Seismic Experiments

Borehole Televiewer

Permanent Triaxial Seismic Station

Precision Long-Term Pressure Measurements

Short-Period Pressure Measurements

Crustal Deformation Observatory

Vertical Seismic Array

High-Frequency Seafloor Seismic Array pour l'Exploitation de la Mer) to place instruments and to carry out well logging in boreholes in the deep sea without a drill ship. The Campagne FARE (Faisabilité Re-Entrée) field

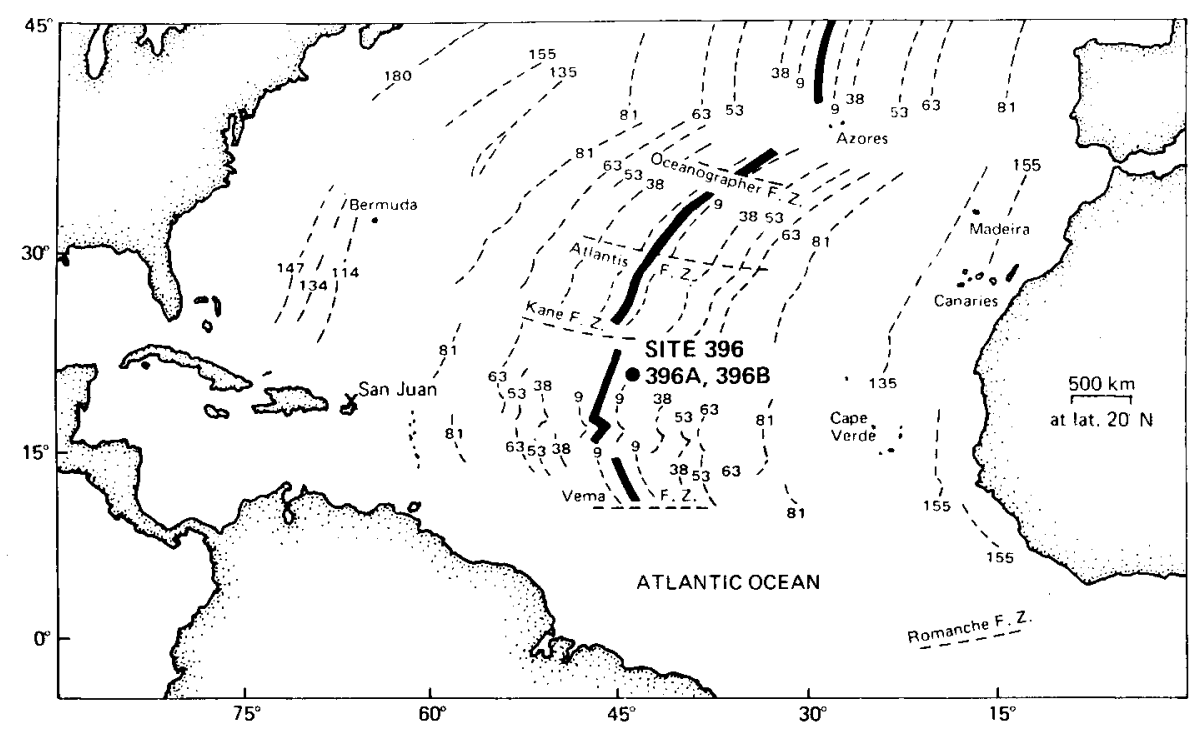

Fig. 1. Location of DSDP Site 396 
dure. They are an asset that can be exploited to carry out a broad range of scientific experiments to study geological, geophysical, and geochemical processes in the seafloor. The development of wireline reentry technology is a significant step in reaching the goal of routinely instrumenting boreholes in the deep sea.

\section{Scientific Objectives of Wireline Reentry}

In February 1987 a meeting was held at Scripps Institution of Oceanography, La Jolla, Calif., to summarize the scientific benefits that would arise from a wireline reentry capability [Langseth and Spiess, 1987]. A list of the borehole experiments included in their report is given in Table 1. Remedial logging could be carried out in holes that were never logged, had poor quality logs, or had key logs missing. New logging techniques, developed since the hole was drilled, could be run without bringing back the drill ship. Short-term experiments requiring a few days and a second ship (such as Oblique Seismic Experiments) could be carried out with wireline reentry from a single ship on a schedule independent of the drill ship. Long-term

installations, such as borehole seismic stations for earthquake studies could be emplaced and maintained using the wireline reentry technology. Tools, currently too large to emplace through the drill string from the drill ship could be deployed. Boreholes could provide the focus for long-term seafloor observatories in which a broad range of geoscience parameters could be measured. Although many of these objectives can be carried out with a drill ship, the wireline reentry capability will let the drill ship concentrate on drilling holes and thus increase the cost effectiveness of that expensive resource. Let drill ships do what they do best-drill.

Langseth and Spiess [1987] identified 29 sites drilled before 1987 that had reentry cones. An updated list is given in Table 2. Thirty-six holes are either deeper than $300 \mathrm{~m}$ into sediment or were drilled to basement. Of course, the currently active Ocean Drilling Program continues to drill new holes. With the advent of wireline reentry technology, holes can be drilled with special attention paid to optimizing their future use, for example, setting casing at least to basement, fishing out broken or lost apparatus, leaving the hole filled with mud to improve hole stability.

TABLE 2. Reentry Holes as of August 1988

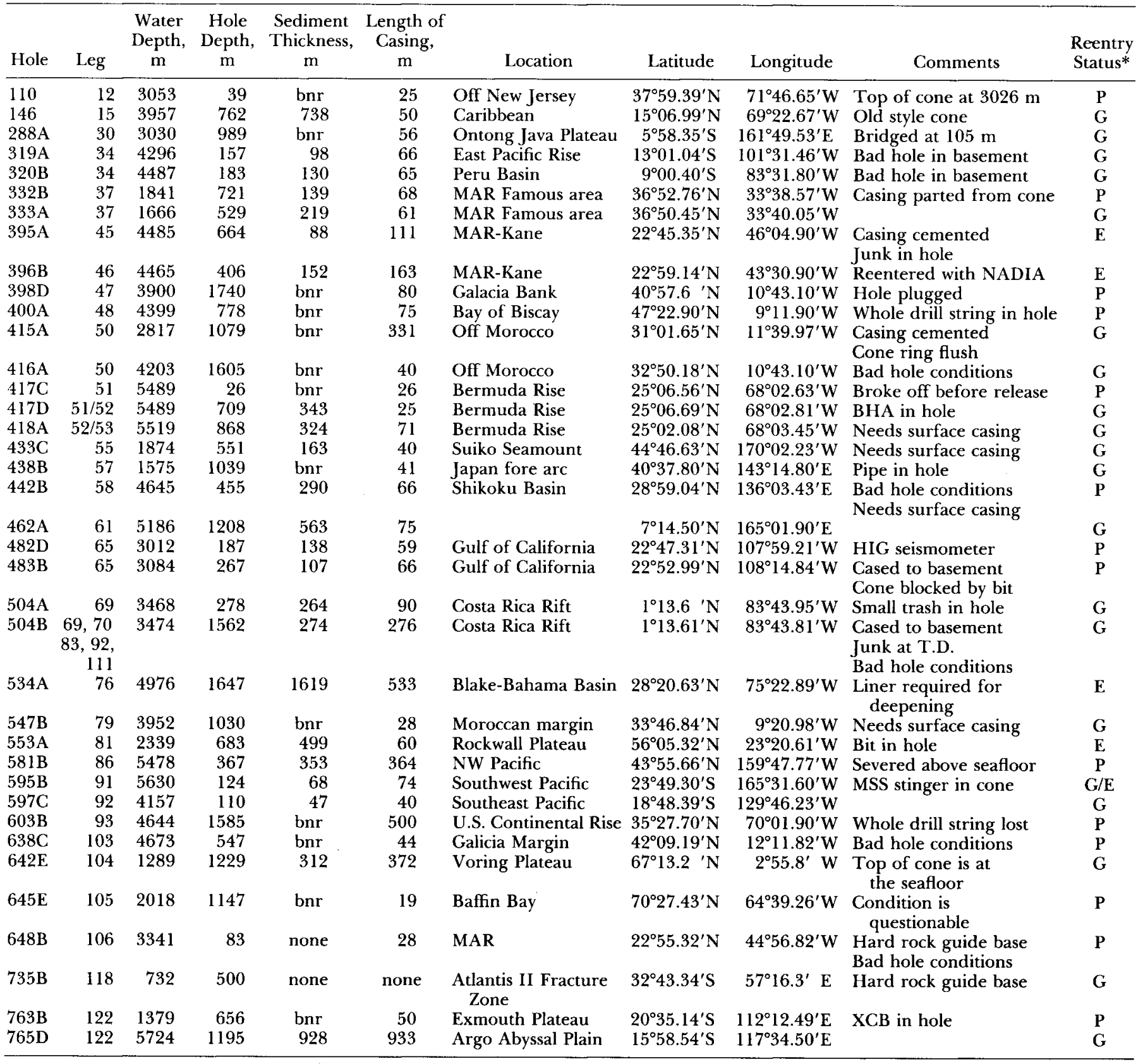

bnr, basement not reached; N/R, not reported in initial report chapter; MAR, Mid-Atlantic Ridge.

${ }^{*} \mathrm{G}$, good; $\mathrm{P}$, poor; $\mathrm{E}$, excellent. 
The most interesting holes for ocean crustal studies such as 504B, 417D, 418A, 395A, and 396B are all candidates for more detailed studies using wireline reentry. Also, many of the objectives of future drilling on the East Pacific Rise will require repeated use of holes. Due to the small hole size (about 4 inches, or $102 \mathrm{~mm}$ ) of the bare rock drilling capability currently under development, wireline reentry will be essential to get conventional size logging tools into holes.

In April 1988 a meeting on Downhole Seismometers in the Deep Ocean was convened at Woods Hole Oceanographic Institution, Woods Hole, Mass. [Purdy and Dziewonski, 1988]. The issue of extending the World Wide Standard Seismograph Net to include seafloor seismometers in boreholes was discussed. The period range of interest varies from 0.1 to $1000 \mathrm{~s}$. At the meeting, wireline reentry was identified as one of the important technological developments that would make such stations possible.

\section{NADIA System}

NADIA is a nonpropelled, free-falling device [Legrand et al., 1988]. Descent to the seafloor and return to the surface are achieved by gravity and buoyancy. The horizontal displacement between the landing point and the cone location is achieved by the submersible.

NADIA is composed of four subsystems (see Figure 2), which are described below.

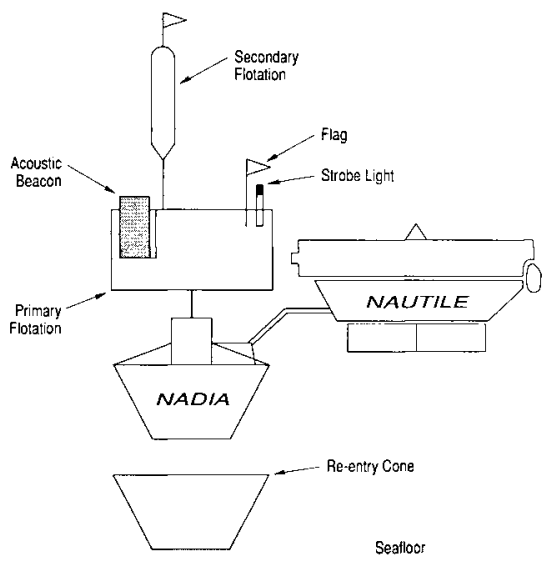

Fig. 2. General configuration of the NADIA deployment system.

- A mainframe, built of welded aluminum alloy tubes, fitted with a winch and its hydraulic control system, the logging tool, the electrohydraulic connector, a $10-\mathrm{m}$ umbilical link to the submersible, and ancilliary equipment (mechanical releases, dead weights, cable cutter, etc.).

- A main flotation assembly supporting the weight of the mainframe. It is fitted with an acoustic navigation beacon for tracking NADIA during the vertical trips and rendezvous with the submersible.

- A secondary flotation assembly released to ballast the mainframe and to dock it down in the reentry cone.

- A descent dead weight, released by the submersible before moving NADIA to the reentry cone.

A logging operation with NADIA proceeds in the following steps (Figure 3).

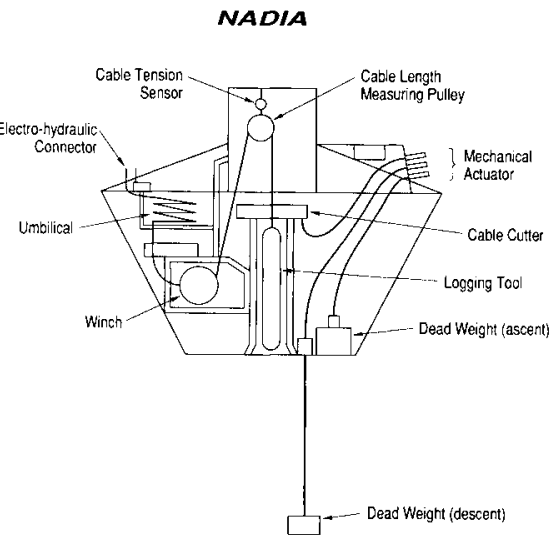

Fig. 3. Detail of the NADIA frame showing winch, tension and depth indicators, logging tool, and release weights.

1. Launching of the frame and the flotation assembly when the ship is in a position that gives the closest impact of the system from the cone.

2. Landing at the sea bottom. Length between descent weight and frame is chosen to prevent NADIA from overshooting or hitting the seafloor.

3. The submersible dives. Rendezvous with NADIA with the help of the acoustic navigation system and a flashlight. The submersible holds NADIA with one arm, adjusts her ballast to become neutrally buoyant with NADIA and releases the descent weight. The submersible moves NADIA toward the cone using its propulsion system.

4. Hovering of NADIA above the conethe secondary flotation assembly is released and NADIA is set in the cone.

5. The submersible connects with the electrohydraulic connector to NADIA.

6 . Lowering the logging tool. Winch control and data acquisition are in the submersible sphere. If the tool is blocked, the wire tension decreases and the operator stops the winch.

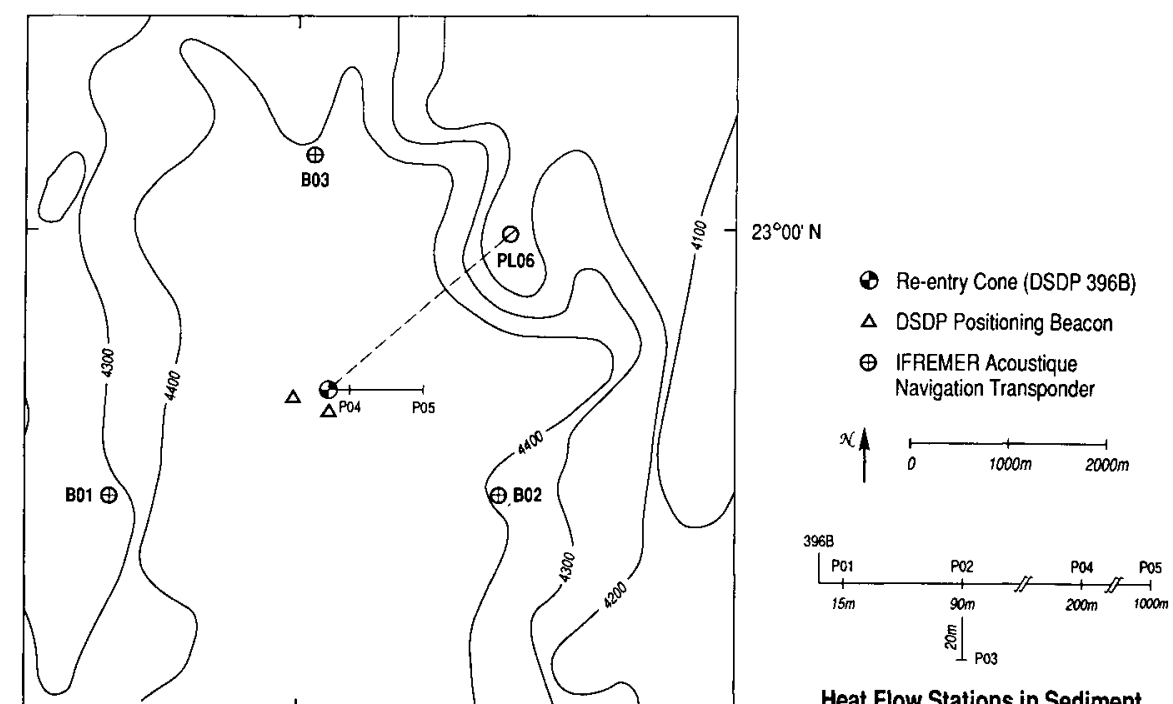

$43^{\circ} 31^{\prime} \mathrm{N}$

Heat Flow Stations in Sediment

Fig. 4. Map of transponders reentry cone, and bathymetry for Campagne FARE at Site 396 .
7. Raising the logging tool back in NADIA's frame. This operation is similar to phase 6. If the tool gets blockd in the hole, and if it cannot be worked free by operating the winch back and forth, two levels of security are available.

- A shear pin rated at $6000 \mathrm{~N}$ provides a weak point at the cable head. A fishing neck at the tool's upper end will permit the use of the fishing overshot in use on board the $D / V$ Joides Resolution.

- A hydrostatic cable cutter is fitted in NADIA's frame. In case the shear pin cannot be used, the cable can be cut to set the system free from the cone. ging tool is raised back in the frame. The submersible disconnects the electrohydraulic link and replaces it in the basket.

9. The submersible holds NADIA, lifts it up out of the cone and moves a few meters off. The ascent weight is released. NADIA is set free and pops up to the surface.

10. The system is recovered on board the ship.

\section{Reentry Tests}

Upon reentry at the site, a long-baseline transponder network was installed and referenced to Global Positioning System (GPS) satellite navigation (Figure 4). The acoustic network was used to navigate the submersible,

Nautile, and the mother ship, Nadir. We knew the cone location within $200 \mathrm{~m}$ from satellite fixes taken during drilling in 1976. The cone was located on the first dive within one hour of landing on the seafloor.

A photograph of the reentry cone is shown in Figure 5. Normally, the bottom of the cone is intended to be on the seafloor, but at Site 396 the cone sank into the mud until the top of the cone was $1 \mathrm{~m}$ below the seafloor (bsf). We had hoped that the cone would be a sonar target. However, an old DSDP transponder was still at the site and this was a target that aided the finding of the cone. Figure 6 shows NADIA emplaced in the reentry cone.
8. At the end of the operations the log- 
A summary of the 11 dives made on the cruise is given in Table 3 . Initially, two dives were used for each reentry attempt. The logging device is installed on NADIA on the sur face. The first dive deploys and emplaces NADIA, and the second dive carries out the logging run and recovers NADIA. We carried out four reentries in this fashion, and a fifth reentry was carried out by deploying and recovering in one dive.

NADIA was emplaced on the second dive with a water-sampling device built by Scripps Institution of Oceanography. The next two dives were used in systems testing and succeeded in lowering the sampler (outside diameter of $100 \mathrm{~mm}$ ) to $170 \mathrm{~m}$ bsf. The hole had been cased with 11-inch (298 $\mathrm{mm})$ casing to $170 \mathrm{~m}$ through $150 \mathrm{~m}$ of sediment and 20 $m$ of basalt. The drill bit diameter was $97 / 8$ inch $(251 \mathrm{~mm})$.

The second reentry on dives five and six ran a temperature probe (outside diameter $200 \mathrm{~m}$ ) to $204 \mathrm{~m}$. The third reentry on dives seven and eight ran the water sampler again to $301 \mathrm{~m}$, and the ninth dive ran a dummy

TABLE 3. Campagne FARE Dive Summary

\begin{tabular}{|c|c|c|c|}
\hline Number & Date & Passenger & Task \\
\hline 1 & July 25 & Harmegnies & $\begin{array}{l}\text { Search for cone } \\
\text { do heat flow } \\
\text { released two old DSDP transponders }\end{array}$ \\
\hline 2 & July 26 & Echardour & emplace NADIA \\
\hline 3 & July 27 & Legrand & $\begin{array}{l}\text { reentry test to } 1 \mathrm{~m} \\
\text { water sampler }\end{array}$ \\
\hline 4 & July 28 & Legrand & $\begin{array}{l}170-m \text { reentry } \\
\text { release NADIA }\end{array}$ \\
\hline 5 & July 29 & Floury & $\begin{array}{l}\text { emplace NADIA } \\
\text { 204-m reentry } \\
\text { temperature probe }\end{array}$ \\
\hline 6 & July 30 & Alliet & $\begin{array}{l}\text { release NADIA } \\
\text { photography and reconnassiance } \\
\text { survey of sediment pond }\end{array}$ \\
\hline 7 & July 31 & Floc'h & $\begin{array}{l}\text { emplace NADIA } \\
300-m \text { reentry } \\
\text { water sampler }\end{array}$ \\
\hline 8 & August 1 & Pozzi & $\begin{array}{l}\text { release NADIA } \\
\text { do heat flow }\end{array}$ \\
\hline 9 & August 2 & Loaec & $\begin{array}{l}\text { emplace NADIA } \\
301-m \text { reentry } \\
\text { dummy probe } \\
\text { release NADIA }\end{array}$ \\
\hline 10 & August 3 & Raer & $\begin{array}{l}\text { emplace NADIA } \\
310 \text {-m reentry } \\
\text { temperature probe }\end{array}$ \\
\hline 11 & August 4 & Stephen & $\begin{array}{l}\text { release NADIA } \\
\text { survey Hole } 396\end{array}$ \\
\hline
\end{tabular}

TABLE 4. Depth Summary in Hole 396B Below Lea Level, Below Seafloor $\mathrm{m}$ $\mathrm{m}$ Into Basement,

Mud-line

$16^{\prime \prime}$ casing

Sediment-Basement Contact

$113 / 4^{\prime \prime}$ Casing

Water Sampler Probe 1

Temperature Probe 1

Water Sampler Probe 2

Temperature Probe 2

Dummy Probe

Top of Fill

Bottom of Hole probe (outside diameter of $150 \mathrm{~mm}$ ) to the same depth. The final two dives ran the temdives, five logging runs were carried out. Ta4 summarizes the significant depths at

\section{Scientific Background of Site 396 and Preliminary Results}

DSDP Sites 395 and 396 (Legs 45 and 46) were part of a designated program of deep penetrations into layer 2 of oceanic crust an Atlantic transect. Hole 396B occuped the most time on Leg 46 and penetrated a which a serious logging attempt in layer 2 Kirkpatrick, 1978]

The importance of logging lies in the fact that it yields information on the physical and structural information on that part of the baperature probe a second time to $301 \mathrm{~m}$. In 11 Hole 396B. The engineering tests of the NAsystem were an unqualified success. salt column of layer 2 that is not recovered in the drilling process. Such losses are often very large, particularly in zones that show alteration and brecciation. Hole $396 \mathrm{~B}$ is a typical example of this, with core recoveries in the upper $150 \mathrm{~m}$ of layer 2 being very low as a result of brecciation. Previous logging consisted of logs below the point of cementation of the well casing (about $165 \mathrm{~m} \mathrm{bsf}$ ) to a total depth of about $380 \mathrm{~m}$ bsf, i.e., $230 \mathrm{~m}$ into layer 2. A standard set of Schlumberger logs for gamma ray, density, neutron porosity, resistivity, and sonic velocity was run. The gamma ray, porosity, and resistivity logs were of great importance in that they confirmed the thickness and relative permeability of the brecciated sections of the hole.

In addition to the logging program, a detailed program of temperature measurements in the sediment column (three measurements) and into the basalt was carried out [Erickson and Hyndman, 1978]. The former led to an estimate of the heat flow in the sediment column of $0.54 \mu \mathrm{cal} \mathrm{cm} \mathrm{cm}^{-2} \mathrm{~s}^{-1}$ (about $17^{\circ} \mathrm{C} \mathrm{km}^{-1}$ ), which was of the same order of magnitude as the site survey heat flow data $\left(0.27\right.$ and less than $0.7 \mu \mathrm{cal} \mathrm{cm} \mathrm{cm}^{-2} \mathrm{~s}^{-1}[P$ urdy et al., 1978]. From the small change of $0.1^{\circ} \mathrm{C}$ from bottom water temperatures of $2.52^{\circ} \mathrm{C}$, Erickson and Hyndman [1978] concluded that at least to a depth of $20 \mathrm{~m}$ into layer 2, i.e., about $170 \mathrm{~m}$ bsf, downward movement of water must occur. This implies the motion of bottom water into layer 2 , a phenomenon also observed in Site 395 [Becker et al., 1984; Langseth et al., 1984] and Site 504B [Becker et al., 1983, 1985]. Kirkpatrick et al. [1978] concluded that the principle reason for this inflowing water may be the breccia zones deeper down in the hole, though temperature log ging was stopped only $20 \mathrm{~m}$ into layer 2.

During Campagne FARE, two temperature logs were run, one to 204 bsf and one to 301 $\mathrm{m}$ bsf. The results are shown in Figure 7.

These results indicate that continued flow of bottom water occurs in this hole but that the flow into the bottom part of the hole is severely hampered by the presence of a fill consisting of a mixture of sands and bentonite to $300 \mathrm{~m}$ bsf. Nonetheless, the continued flow into the hole supports the essential continuity of open pore spaces and cracks over large lateral distances in layer 2 . Under normal circumstances, this flow is fed from the exposed rocks at the edge of the sedimentfilled depression. This model was invoked by Erickson and Hyndman [1978] to explain the low heat flow in this area. In addition, a water-sampling program was carried out designed to study the composition of the seawater filling the hole. Such studies may indicate the presence of down-welled bottom water and/or changes in the chemical composition as a result of exchange and reaction with the basalts [Gieskes et al., 1984; McDuff, 1984; Mottl et al., 1983, 1985; Leg 102 Shipboard Scientific Party, 1986]. Preliminary results indicate the presence of bottom water to at least $260 \mathrm{~m}$ bsf.

\section{Conclusions}

Campagne FARE has clearly demonstrated the feasibility of reentering DSDP Hole 396B in a water depth of $4455 \mathrm{~m}$. The hole was cased $170 \mathrm{~m}$ to basement and was open a fur ther $133 \mathrm{~m}$ into open hole in the basalt. The logging measurements indicate that water is still flowing downhole 12 years after drilling. 


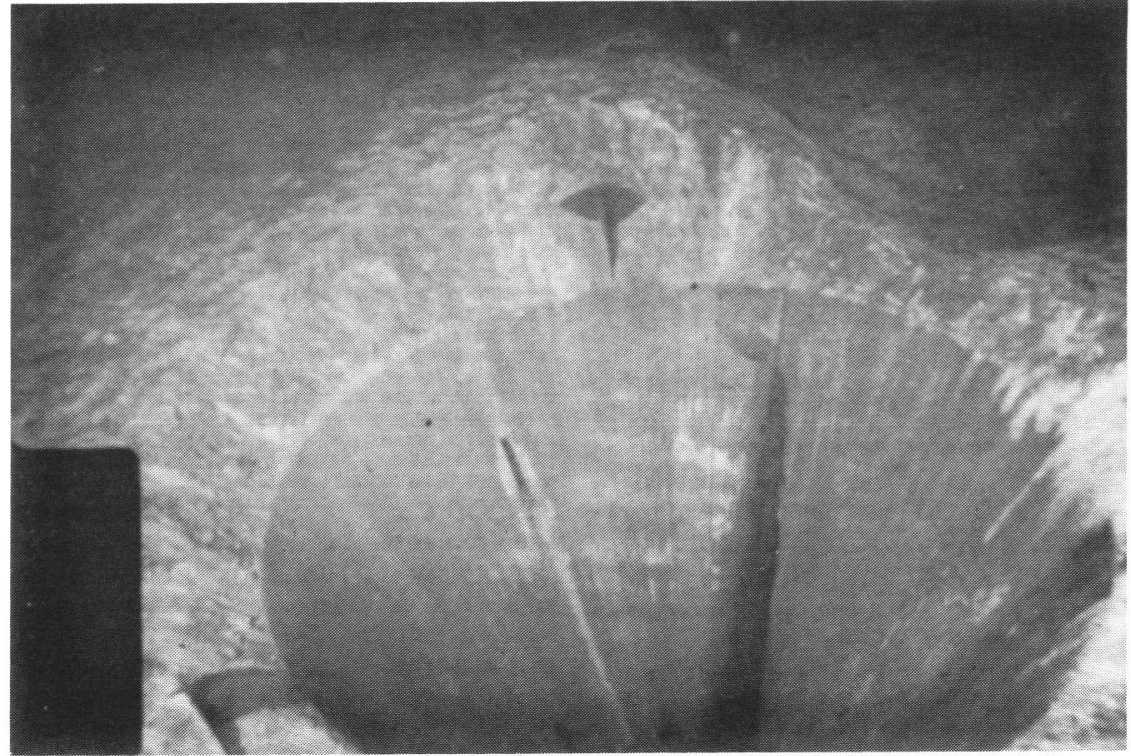

Fig. 5. Photograph of reentry cone at DSDP Site 396.

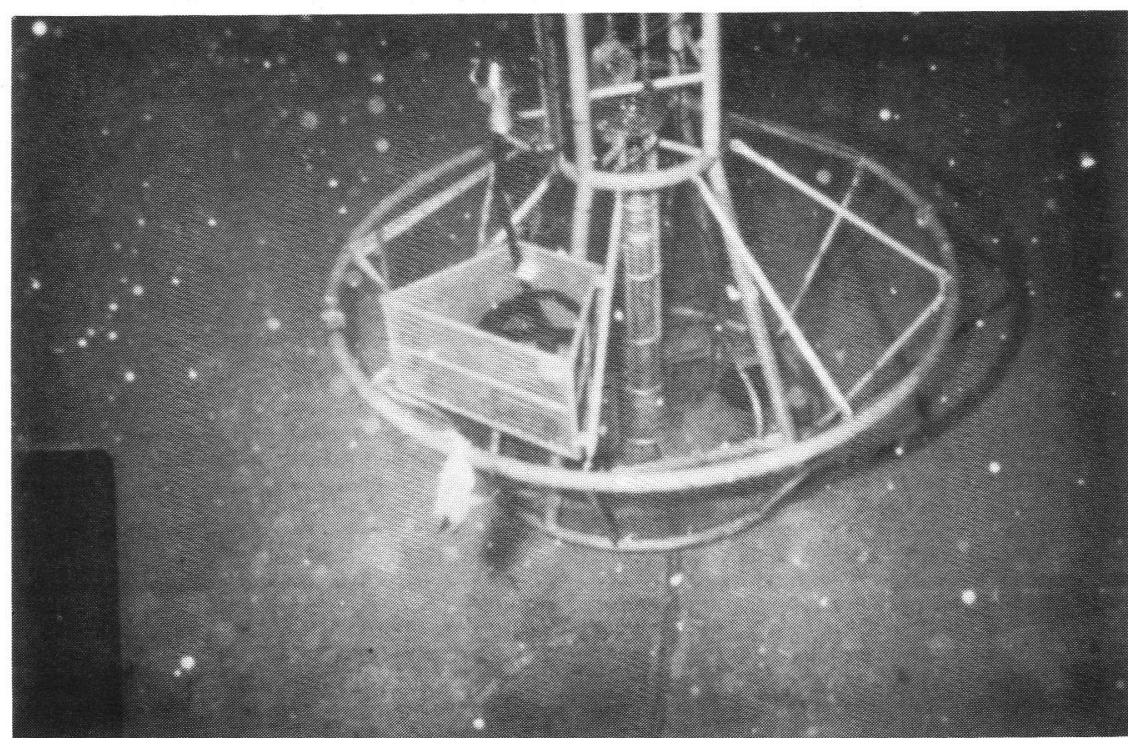

Fig. 6. Photograph of NADIA on the seafloor at Site 396.

The acronym for the project, FARE, originally short form for Faisabilité Re-Entrée

(feasibility of reentry), can now be changed to Fait Re-Entrée (fact of reentry).

\section{Acknowledgments}

We would like to thank Captain Horde, the officers and crew of R/V Nadir and P. H. Nargeolet and the operating team of Nautile for providing very efficient technological support for the above tests.

The project was financed by IFREMER through its two departments, Direction de l'Environnement et de la Recherche Oceanique (DERO) and Direction de l'Ingénierie et de la Technologie (DIT). We would like to thank particularly B. Biju Duval and J. P. de Loof for providing the necessary support in personnel, ship time, and facilities.

The project NADIA was strongly supported since the beginning by ODP-France through the group "Mesures dans les puits" (downhole measurements) under the responsibility of G. Pascal and J. P. Pozzi. We appreciate their precious help.

Glen Foss, Matt Salisbury, Mark Langseth, and Fred Spiess have been long-time enthusiasts of wireline reentry and we appreciate

their support. Pat Thompson and Glen Foss, from the Ocean Drilling Project at Texas A\&M University, College Station, assisted in preparing Table 2.

\section{References}

Becker, K., M. G. Langseth, and R. P. von Herzen, Deep crustal geothermal measurements, Hole 504B, Costa Rica Rift, J. Geophys. Res., 88, 3447, 1983.

Becker, K., M. G. Langseth, and R. D. Hyndman, Temperature measurements in Hole 395A, Leg 78B, Initial Rep. Deep Sea Drill. Proj., 78B, 689, 1984.

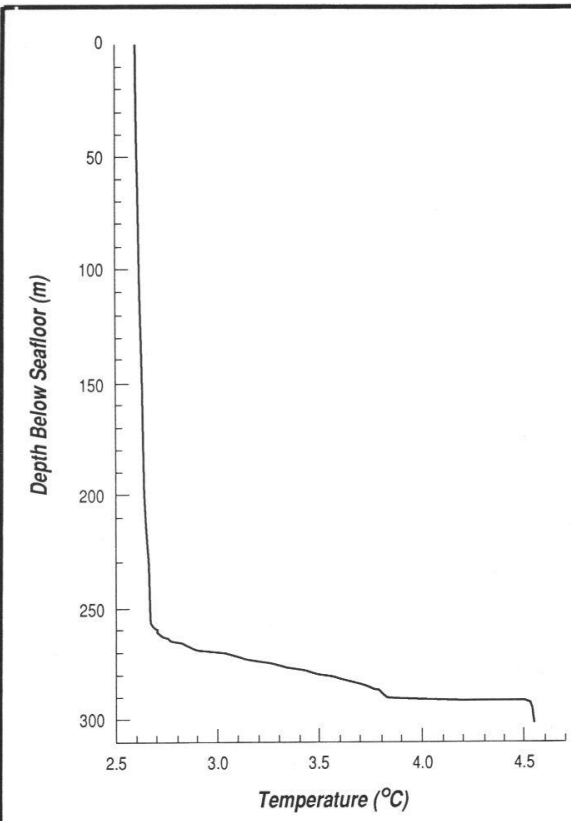

Fig. 7. Preliminary temperature-depth profile obtained with the NADIA system.

Becker, K., M. G. Langseth, R. P. von Herzen, R. N. Anderson, and M. A. Hobard,

Deep crustal geothermal measurements, Hole 504B, DSDP Legs 69, 70, 83, and 92, Initial Rep. Deep Sea Drill. Proj., 83, 405, 1985.

Dmitriev, L., J. R. Heirtzler, and the Leg 46 Scientific Party, Introduction and explanatory notes, Initial Rep. Deep Sea Drill. Proj., 46, 3, 1978a.

Dmitriev, L., J. R. Heirtzler, and the Leg 46 Scientific Party, Holes 396A and 396B, Initial Rep. Deep Sea Drill. Proj., 46, 15, 1978 .

Erickson, A. J., and R. D. Hyndman, Downhole temperature measurements and thermal conductivities of samples, Site 396 Deep Sea Drilling Project Leg 46, Initial Rep. Deep Sea Drill. Proj., 46, 389, 1978.

Gieskes, J. M., M. Kastner, J. Erzinger, J. Boulegue, and S. R. Hart, Geochemical studies in Hole 504B, Leg 92, Initial Rep. Deep Sea Drill. Proj., 92, 547, 1984.

Kirkpatrick, R. J., Results of downhole geophysical logging Hole 396B, DSDP Leg 46, Initial Rep. Deep Sea Drill. Proj., 46, 401, 1978.

Kirkpatrick, R. J., and the Leg 46 Scientific Party, Leg 46 cruise synthesis: The petrology, structure, and geologic history of Site 396, Initial Rep. Deep Sea Drill. Proj., 46, 417, 1978.

Langseth, M. G., and F. N. Spiess, Science opportunities created by wireline reentry of deep sea boreholes, report, Scripps Institution of Oceanography, Feb. 23-24, 1987,

Joint Oceanographic Institutions, Washington, D.C., 1987.

Langseth, M. G., R. D. Hyndman, K. Becker, S. H. Hickman, and M. H. Salisbury, The hydrogeological regime of isolated sediment ponds in mid-ocean ridges, Initial Rep. Deep Sea Drill. Proj., 78B, 825, 1984.

Leg 102 Shipboard Scientific Party, Site 418: Bermuda Rise, Initial Rep. ODP (Part A), 102, 95, 1986.

Legrand, J., A. Echardour, L. Floury, H. Floch, J. Kerdoncuff, T. LeMoign, G. 
Loaec, and Y. Raer, NADIA: Wireline reentry in deep sea boreholes, Proc. Oceans '88 Conf. MTS/IEEE, 2, 602, 1988.

McDuff, R. E., The chemistry of interstitial waters from the upper ocean crust, Site 395, DSDP Leg 78B, Initial Rep. Deep Sea Drill. Proj., 78B, 795, 1984.

Mottl, M. J., R. N. Anderson, W. J. Jenkins, and J. R. Lawrence, Chemistry of waters sampled from basaltic basement in DSDP Holes 501, 504B, and 505B, Initial Rep. Deep Sea Drill. Proj., 69, 475, 1983.
Mottl, M. J., E. R. M. Druffel, S. R. Hart, J. R. Lawrence, and E. S. Saltzman, Chemistry of hot waters sampled from basalt basement in Hole 504B, DSDP Leg 83, Costa Rica Rift, Initial Rep. Deep Sea Drill. Proj., $83,315,1985$.

Purdy, G. M., and A. M. Dziewonski, Permanent downhole seismic observatories in the deep ocean, JOI/USSAC Workshop Rep., Joint Oceanographic Institutions, Washington, D.C., 1988

Purdy, G. M., H. Schouten, J. Crowe, D. L.
Barrett, R. K. H. Falconer, G. B. Udintsev, N. A. Marova, V. M. Litvin, G. M. Valyashko, V. M. Markushevich, and V. V. Zdorovenin, IPOD Survey Area AT-6: A site survey, Initial Rep. Deep Sea Drill. Proj., 45, 39, 1978.

Salisbury, M. H., J. H. Scott, C. A. Auruox, et al. Initial Rep. ODP (Part A), 102, 95, 1986.

Stephen, R. A., F. K. Duennebier, D. R. Bellows, and A. Inderbitzen, Wireline reentry test on DSDP Leg 88, Initial Rep. Deep Sea Drill. Proj., 88, 59, 1987.

\section{Manuscripts Before the Mast}

\author{
PAGES 729, 731
}

\section{Reflections of an Outbound Editor}

Two and a half years of service as an edito of the Journal of Geophysical Research-Solid

Earth and Planets have given me some experiences and insights about writing and reviewing research reports, which I offer here as an editorial swan song. Let me start with a few of the highlights of my tenure.

- The author at a Pacific atoll observatory who wrote that the arrival of his long-awaited acceptance letter cured him of malaria.

- The referee who copyrighted his review so that the authors could not incorporate his corrections without violating the copyright.

- The reviewer who blamed the authors for someone else's unsuccessful tenure application, which led to a furious and even more fatuous reply to the offending reviewer by one of the authors, suggesting that the reviewer's science was no more informative than stirring the entrails of dead sheep (although "Dead Sheep Entrails" did sound like a good topic for a Special Issue). From this exchange and the foregoing I learned that some reviews are best returned to sender.

- The many reviewers who took umbrage that my admonishment to reviewers (the offspring of "Sheep"), "to be polite in all remarks to be seen by the author," was a preemptive strike on their history of sending lurid reviews to the editors.

- The guest Associate Editor of a Special Issue who pressed his authors to meet the submission deadline, only to fail to get either his own paper or his introduction to the Special Issue written.

- The author whose paper was destroyed beyond reconstitution by a typhoon

- The author who asked me if I thought he should submit a paper to a Special Issue and, when I encouraged him to do so, wrote the guest $\mathrm{AE}$ that his paper had already been accepted and he would just be putting the finishing touches on it.

- The authors of a 116-page treatise who, when I wrote that I wanted their manuscript split into two papers (the first of which was accepted and the second provisionally so), called me in a rage that I had "dealt them a deathblow."

- The second author who refused to make any requested revisions to the manuscript of the then-absent first author (his graduate student) because that would put the student's work in a more favorable light than it deserved.

- The third-world author from whom I received a steady stream of greeting cards but no revised manuscript.

- The Associate Editor whose reviews carried this disclaimer in microscopic print:

I am not responsible for the contents of this letter but am being forced to write it by terrorist graduate students.

- Getting manuscripts from everyoneregardless of discipline-who figured I owed them a favor or to whom I was related by marriage.

I also would like to commend for valor:

- The many unselfish scientists who performed saintly acts for third-world and Eastern European authors by translating and typesetting the text into standard English, redrafting figures, and helping the authors respond to reviews.

- The AGU Publications staff, who put up with my ever-mounting requests for more computer hardware, software, printers, copiers, furniture, file cabinets, phone lines, and assistant's hours, and who were forbearing in the face of my constant whine for fewer manuscripts, weekly page-charge-experiment reports, monthly expense and manuscript reports, and semiannual editor's reports.

Standing in judgment on papers sent to me during the same period when I was submitting manuscripts to other imperious editors taught me something about my own frailties as an author and reviewer. Here is my perception of some of the key problems encountered in writing and reviewing scientific papers.

\section{Writing}

The editorial message of JGR is simple: Give us your best work. That does not, by necessity, mean your longest treatise or your experiment with the latest technology, but your most important research report and, because of this, a finely crafted manuscript. Perhaps the principal reason why submitted papers are not the best they can be is that many are sent into the world about two months premature. What happens to these "preemies" is that the editor and referees are forced to decode the text, reorganize and streamline the prose, and search for the key contribution of the investigation. More often than not, the premature delivery also means matching sketchy Figure 9 to its caption as Figure 10 and its callout as Figure 11. Under such circumstances, reviewers tend to glaze over and put the paper under a pile somewhere. Everyone goes comatose.

I have found that authors who can summon the patience to ask their colleaguesboth someone within the field and someone well outside it-to read their paper before it is submitted fare immeasureably better in the review process. Before a paper is written, ask yourself, to whom is this paper addressed? Write for the widest possible audience, so that your efforts are rewarded by readers. Instead, most of us write papers with just a few enemy referees in mind. That leads to a bunker mentality. The manuscripts are written defensively, encrypted with jargon, and with protected ramparts rather than exposed logic and flaws. Papers the rest of us can understand, and in which shortcomings are acknowledged along with successes, will gain credibility and their authors maintain integrity.

As our last act before submission, most of us place the Conclusions in a trash compactor and turn the key. Voilà! Out comes the abstract. The result is text in its densest packing configuration. Of all the sections in the manuscript, it is the abstract that will be most widely read and thus must be most easily read. The abstract not only telegraphs the key message of the paper, it should also invite people to read further. Use the abstract to tell us why the work was done, what's new and why it's important-with "Details at 11." Too much compression or too many facts rob an abstract of clarity and impact.

\section{Reviewing}

The fundamental purpose of reviewing is to identify ways to make submitted papers better; screening out ill-conceived manuscripts is subservient to this goal. Most referees approach a manuscript like a school marm grading a math test. The paper arrives with a score of 100 and is marked down for every mistake uncovered; the surviving paper has the least red ink in the margins. 